
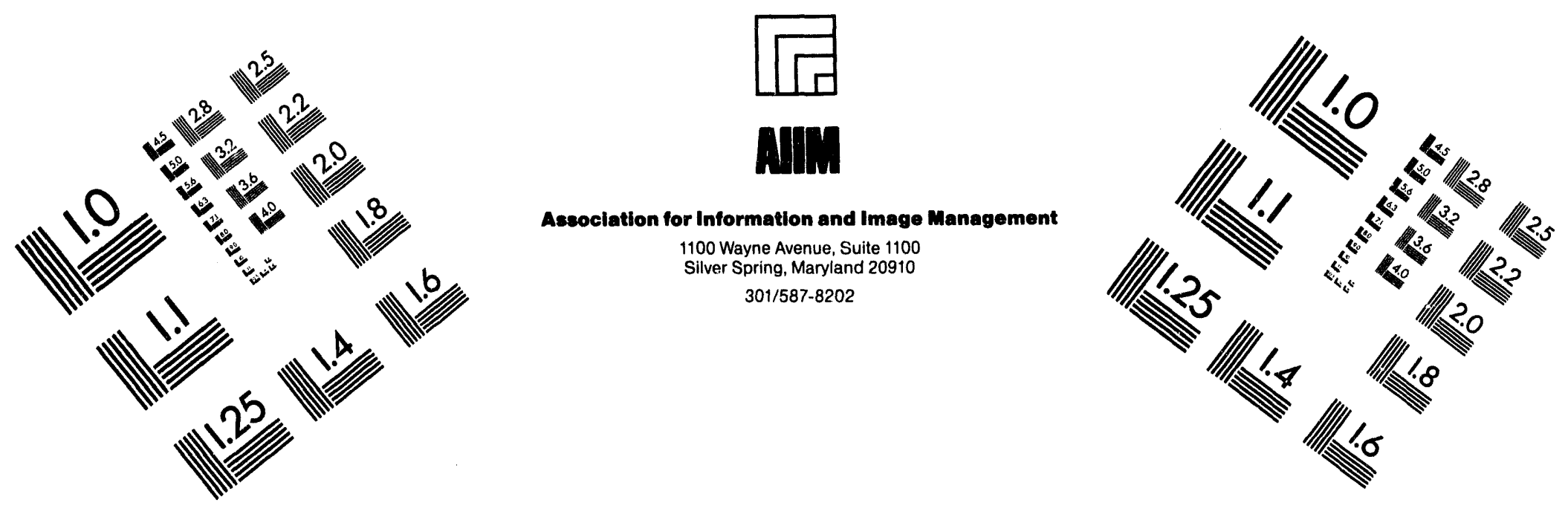

\title{
Centimeter
}

$\begin{array}{llllllllllllllll}1 & 2 & 3 & 4 & 5 & 6 & 7 & 8 & 9 & 10 & 11 & 12 & 13 & 14 & 15 & \mathrm{~mm}\end{array}$

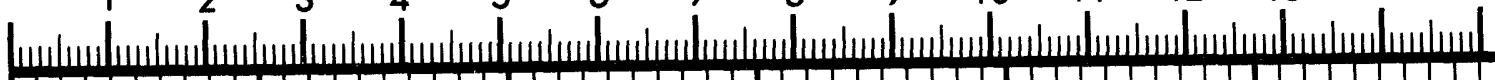

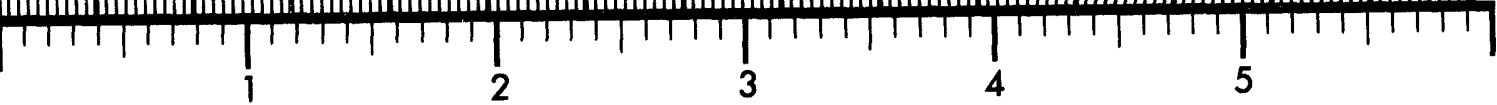

Inches
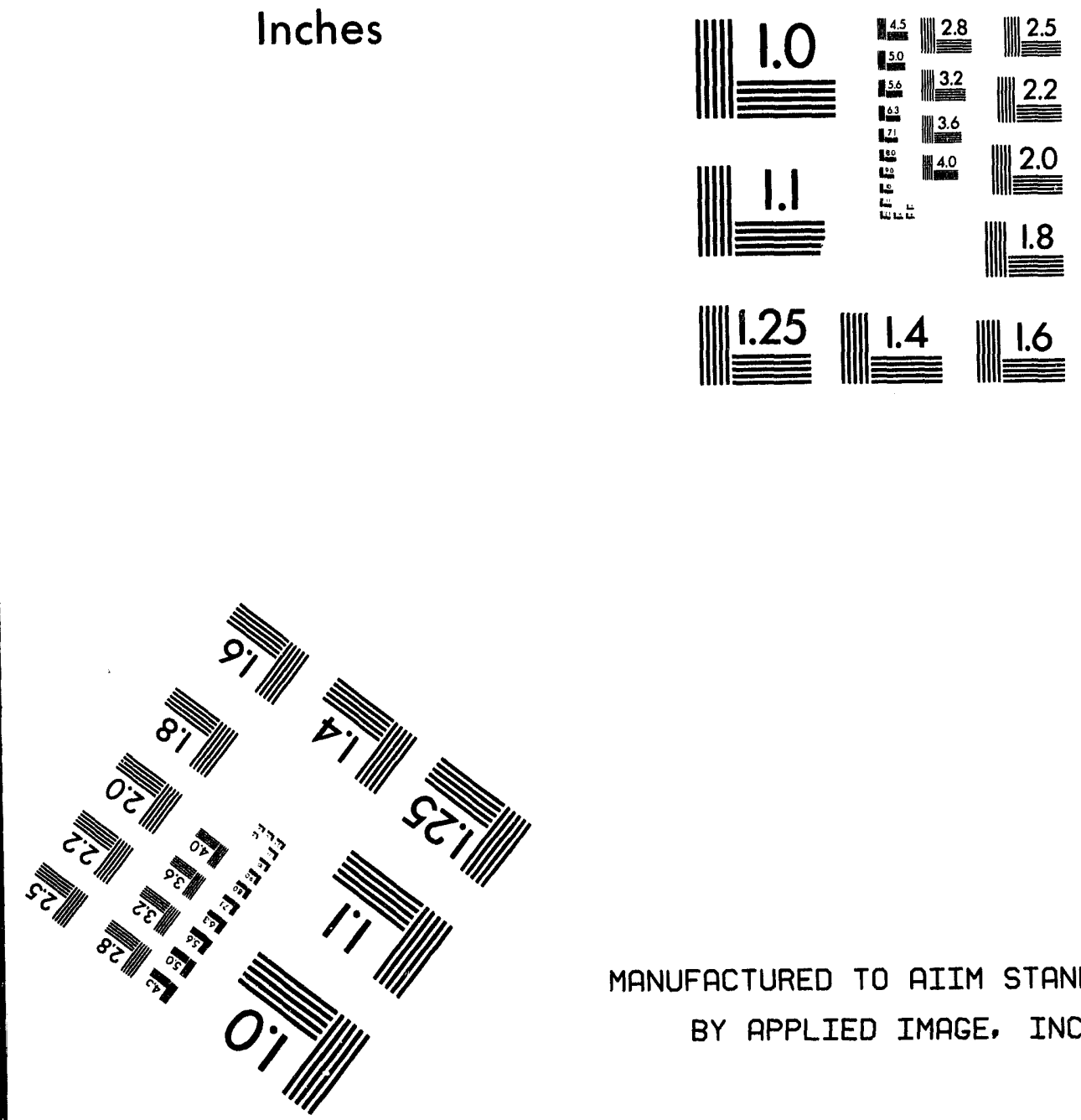

MANUFACTURED TO AIIM STANDARDS

BY APPLIED IMAGE, INC.

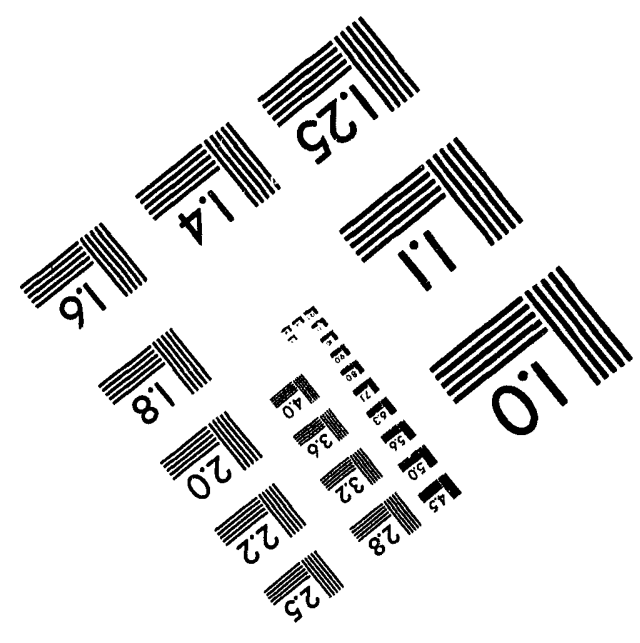



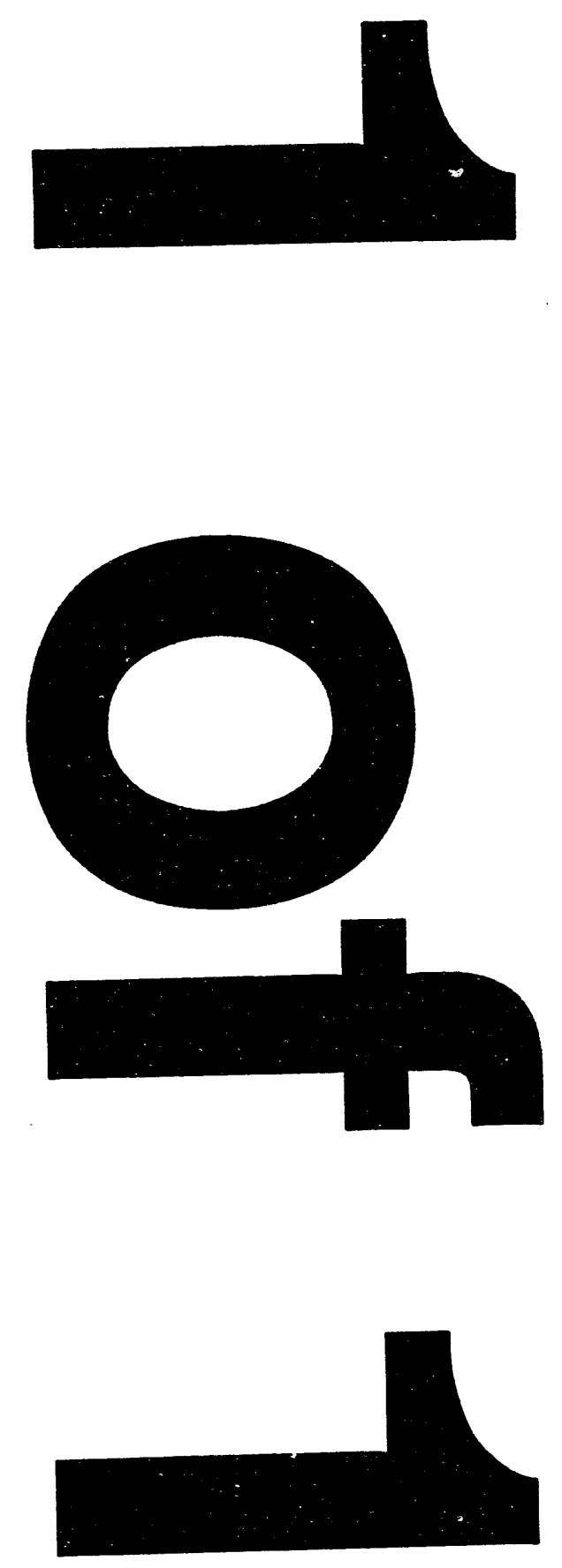


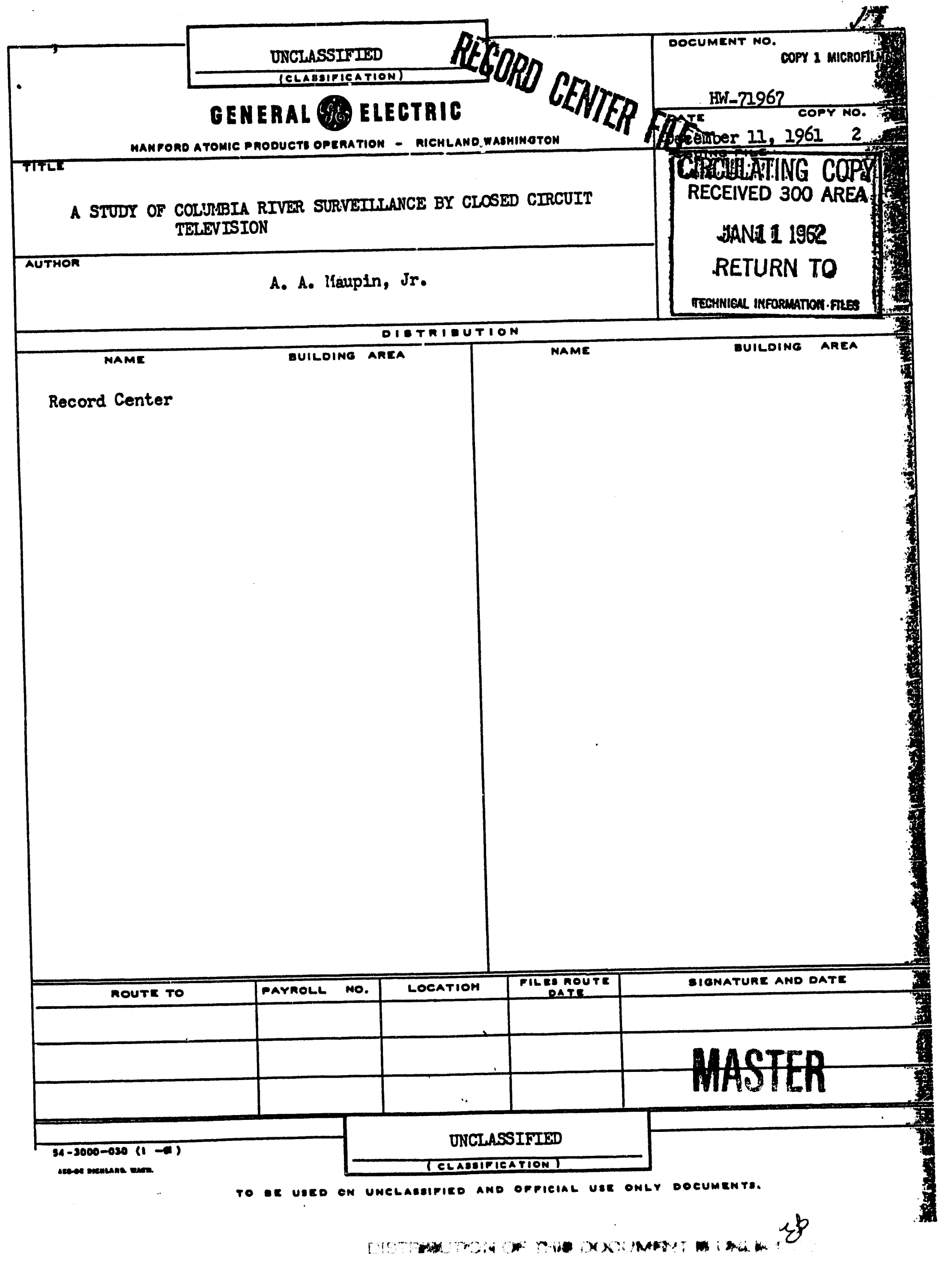




\section{A STUDY OF}

COLONBIA RIVER SURVISTIANICE

BY CLOSTH CIRCUIT THWISISION

Prepared by

A. A. Maupin, Jr.

Rlectricel Desion Subsection

Design Ingineering section

Construction Bngineering and vtilities Operation

December 11, 1961

This document clessifled by

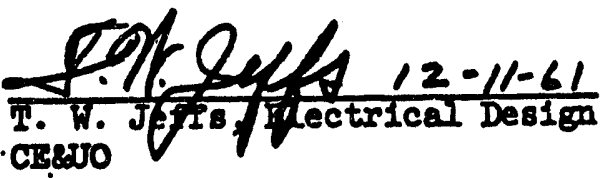

CEstro

MAMFORD ATOMIC PRODUCTS OPRATION

GENERAL ELETRIC 
2.0 BASIS OF BTUDY

3.0 VIDICOI VIRSOS IMAGS ORTHICON

4

4.0 IEATSES

5.0 ASPECT RATIO

6.0 ZOON IEISS VGRSUS IEATS TURRET

7.0 NOUNIITIS OF PAII AIID TIIT UIIT

8.0 DOUSTHR

10

9.0 IIUMTIRATION

11

10.0 COITLROL

11

14

11.0 PAII AII TIII BPGEDS

15

12.0 COST ESTDYATH 


\section{A BTUDY OE COLUNBIA RIVER SURVETIIATCS BY CIOST CIRCUIT THIEVIFIOA}

\subsection{SUMARI AND COICIUSION}

Gurrelliance of the Columbia Rirer by closed circuit television does not appear to be economically practical under the conditions set forth in the Basis of Study (Bection 2.0).

To observe a small boat 5000 feet aray requires a $16 \mathrm{~mm}$ lens of 12 Inch focal length. The angle of riew of this lens 18 so small (approximatels 2 degrees) that the river cannot be surveyed ith it by simple panning alone. Alvo, panning speed with this lens must be rery olow--approximately one revolution erery 15 minutes--in order for an object to remain in the fleld of view for P1ve seconds.

It would be technlcally poselble to include an automet1c search program Involving last and low pan, last and slow tilt, and lens change. Aside Irom the technical complexity of such control, the time required to complete one search cjcle would leave ereas of the river unobserved for long perlods of time. There is alao the problem of getting the equipment oyachronized inth the autometic search procrem after it has been intermpted by manual operation.

The river can be survejed by sumple panning alone if the lens focal length is in the range of 1.5 inches. Due to the wide fleld of view of this lens, $1 t$ cannot observe a small boat farther aray than about 600 to possibly 1000 feet. Thus the remaining 4000 feet of the river would be beyond the resolving power of the system when it 18 acanning the river automatically.

R1ter surve1llance at night ifth television 18 not practical beyond 500 to 1000 feet because of the difflculty of providing adequate 1llumination. It seems practical to prorlde a searchilght beam capable of 12luminating a boat at 500 to 1000 leet, horrerer the searchlight beem would be only about 5 degrees vide. A 5 degree beam 1s not adequate for river surve1liance by simple panning alone. It 18 approximately the same angle of viev as that of a 6-1nch lens.

Bearchlights would be of no use in even moderate fog conditions because of 11ght dispersion by water aroplets.

searchlights panning in synchronism with the camers would reveel to interested parties the direction in wich the camera was almed. 


\subsection{BASIB OF STUDY}

\subsection{General Description of Problem}

2.1.1 Current Practice - A patrolmen observes river trafe1c 24 houxs a day, seren days a reek, Irom a 50 foot enclosed tover located on the bank of the river. Under normal daylight conditions the opposite shore line and bluefs $\left(2,000^{\prime}\right)$ and approximately three miles both up and dow the river can be seen by naked eje with close up 1dent1fication obtalned through use of fleld glasses. For night time operation a manuaily operated searchlight is used to sweep the river for moving or floating objects. The searchlight now in use 18 a CROUSB-BIDS type G-40, 12 Inch, DCX-12, Catelog A4082-A. It has a 500 rett 040 spotilght buib, beam cendleporer of 434,000 , lamp lumens of 10,100 and welghs 98 pounds. Indlcated lumens and candlepover are based on G-40 spotlight with 200 hours life. A 640 floodlight of 800 hours life yields a beam candlepower of only 360,000 .

2.1.2 Proposel - To determine wether $1 t$ is feasible to replace the patrolman in the river tower with a remotely controlled closed circult television and searchlight system.

\subsection{General Specilications}

2.2.1 Camera - Blgh resolution, lovest possible foot candle sensitivity to produce a usable plcture; exposed to all types of weather: dust, rain, snow, sleet, 1ce, and temperature ranges from $20^{\circ}$ to $130^{\circ}$ Fahrenhe1t. Equipment for sun protection of vidicon tube is required.

2.2.2 Iens - Blther a $200 \mathrm{~m}$ lens or remotely controlled turret to obtain the best possible scenning of river along with ability to ldentify a type of boat and number of occupants of boat at a distance of 5,000 feet under normal daylight conditions.

2.2.3 Pan and t1lt to operate both the cemera and the searchlight in synchronism. The usual operating ranges of $10^{\circ}$ to $350^{\circ}$ pan and plus or minus $45^{\circ}$ tilt are satisfactory.

2.2.4 All weather housing with window washer and wiper and heat strips for winter operation and fan cooling for sumer operat1on.

2.2.5 The tower contalns a weatherproof room with $120 \mathrm{~V}$ power avallable for the cemera control unit.

2.2.6 Distance from tower to remote control station 18 5,000 feet with poles already in place each 75 to 100 feet for the entire alstance.

2.2.7 Honitor to be a minimum of $17^{\prime \prime}$. 
2.2.8 Controls to be at a mindmim for iferation by patrolman.

a. Contrast and brightness.

b. "Joy stick" control of pan and tilt.

c. Speed adjustment for pan and tilt.

a. Control of elther zoom or turret lens.

e. Iens focus.

1. Operation of window wipers and wasbers.

g. Switch to turn searchlight on or off.

2.2.9 Cont1nuous operation 24 hours a day - 365 days a year - never turned off.

\subsection{VIDICON VERSUS DMAGS ORTHICON}

A trancistorized camera can remain stable without requiring readjustment for at least 100 hours, and probably much longer. A vacuum tube camera will age and drift faster than a transistorlzed unit. The camers should therefore be trans1storlzed; except for the pleture tube, of which there are no transibtor1zed versions.

Both vidicon and image orthicon cameras are avallable transistorized. .

The Image orthicon camera has the sensitivity to produce an image of the river under bright night conditions without artificial light. The Nalcon camera does not have this sensitivity. (One report indicates that a quality vidicon camera usiog the $7735 \mathrm{~A}$ vidicon and an $\mathrm{f}: 1.5$ lens produced a relatively nolsefree picture with scene brightpess of one foot-lambert. The scene was a test chart.)

The cost of an image orthicon camera is about $\$ 20,000$. A quality ridicon camera costs about $\$ 3,500$.

An Image orthicon camera requires 35-mm lenses, whereas the ridicon uses 16-mm lenses. For the same magnification and speed a 35-mm lens has twice the focal length and tilce the diameter of the comparable 16-m lens. To resolve a mell boat at one mile requires a 24-1nch 35-mm leas, or a 12-1nch 26-mn lens.

Consultants advise that an image orthicon camera 18 very couplex and requires frequent attention, possibly as iften as several times a day.

One consuitant advises that an Image orthlcon tube costs $\$ 5,000$ and 18 rated 1,000 hours. Another consultant advises that the cost of a sensitive image orth1con tube 1s about $\$ 3,800$ and that comercial broadcasters assume a 200 hour 11fe for quality pictures. The annual replacement cost for the tube 
alone w111 be $\$ 45,000$ to $\$ 167,000$ depending on which flgares are accepted. Even at the lovrer Ilgure the use of an image orthicon becomes economicaliy unjustiflable for thls application.

The writer has no knowledge of anj image orthicon cameras in use at BAPO.

\subsection{IMISES}

\subsection{Borizontel V1eving Requirements}

Assume a 12-foot-long boat at 5,000 feet. Assume that the malritained horlzontal resolution of the television system is at least 500 11nes. Asinme five lines required to recosenize an object.

$$
\begin{aligned}
& 500 \text { L1nes } \times \frac{4}{3} \text { aspect rat10 }=667 \text { horizontel lines per picture. } \\
& \frac{5 \text { lines }}{12 \text { feet }}=\frac{667 \text { lines }}{x \text { leet }} \\
& x=1600 \text { feet maximum horizontal fleld at } 5000 \text { feet }
\end{aligned}
$$

The nearest equivalent lens is 2-1nch and has a 1250 foot borizontal fleld of view at 5000 feet.

\subsection{Vertical Viewing Requirements}

Assume a 2-foot-high boat at 5000 feet. Assume that the malntained rertical resolution of the television system is 340 lines.

$$
\begin{aligned}
& \frac{5 \text { lines }}{2 \text { feet }}=\frac{340 \text { lines }}{x \text { feet }} \\
& x=136 \text { leet maximum vertical fleld at } 5000 \text { feet }
\end{aligned}
$$

The nearest equivalent lens $1 \mathrm{~s} 12$-1nch and has a 156 loot vertical fleld at 5000 seet.

Thus, the rextical vlewing requirement is the most stringent and a 12-1nch lens is requitred.

\subsection{Vert1cel Resolving Power at 5,000 Feet W1th. 12-Inch Ions}

$$
\begin{aligned}
& \frac{5 \text { Ines }}{x \text { leet }}=\frac{340 \text { lines }}{156 \text { leet }} \\
& x=2.3 \text { feet }
\end{aligned}
$$

A 12-1nch lens should be able to resolve an object which 1s at least 2.3 feet hick and 5,000 feet away. 
THCIASSIIIIA

4.4 Hor1zontel Resolving Pover at 5,000 reet Hith 12-Inch Iens

The horizontal fleld of vier of a 12-1nch lens at 5,000 feet 18208 reet.

$$
\begin{aligned}
& \frac{5 \text { lines }}{x \text { leet }}=\frac{667 \text { ines }}{208 \text { feet }} \\
& x=1.5 \text { feet }
\end{aligned}
$$

A 12-Inch lens under the assumed cond1tions should be able to resolve an object wich is at lesst 2.5 feet long and 5,000 leet array.

\subsection{Focel Length Ratio}

The design of lens turrets 18 such that the ratio of the longest to the shortest focel length lenses should not exceed 6 to 1 if the longer lens is to be kept out of the fleld of view of the shorter one.

This consideration Indicates a 2-1nch lens for the shortest one.

\subsection{Vertical Resolving Power at 5,000 Jeet With 2-Inch Lens}

The vertical field of view of a 2-1nch lens at 5,000 feet 18 about 937 feet.

$$
\begin{aligned}
& \frac{5 \text { lines }}{x \text { feet }}=\frac{340 \text { I1nes }}{937 \text { feet }} \\
& x=13.8 \text { feet }
\end{aligned}
$$

A 2-Inch lens should be able to resolve an object which 18 at least 13.8 feet h1gh and 5,000 leet away. Thus the 1mage of a 2-foot-h1gh boat would be less than one scanning Iine on the monltor screen and would not exist. In other words, a 2-1nch lens used for general autcomatic scanning cannot percelve a 2-foot-h1gh boet at 5,000 feet.

\subsection{Bor1zontal Resolving Pover at 5,000 Feet HIth 2-Inch Lens}

The horizontal fleld of vlew of a 2-1nch lens at 5,000 feet 1 s about 1250 feet.

$$
\begin{aligned}
& \frac{5 \text { Ines }}{x \text { feet }}=\frac{667 \text { Ines }}{1250 \text { feet }} \\
& x=9.4 \text { leet }
\end{aligned}
$$

A 2-1nch lens should be able to resolve an object which 18 at least 9.4 feet long and 5,000 leet away.

The minimum sizes derived in (4.6) and (4.7) are mutually independent. That 16, the object must be at least 9.4 feetlong and 23.8 feet high to be resolved by a 2-1nch lens at 5,000 reet. Bowever, if the object subtends perhaps 3 scanning lines an alert operator may notice that something 1s there that should be examined with a more powertul lens. In1s is a speculation and 
depends hearlif on the contrast of the object with its beckground, the alertness. of the operator, the no1se inherent in the TV system, and the veather conditionse.

\subsection{Intermediate Ienses}

Jour-lens turrets are aratiable. W1 th a 12-1nch and a 2-1neh lens established, there remain two intermediate leases. There will be three intervals of magni- Plcation $(2-x, x-y, y-12)$.

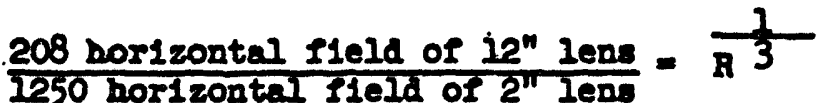

$$
\begin{aligned}
& R=1.818
\end{aligned}
$$

The ratio of the IInear flelds of riew of adjacent lenses should be 1.818 to give equal changes of magniflcation.

$$
208 \times R=378 \text { seet }
$$

The required horlzontel fleld of view of the second most powernul lens is 378 leet. The desired lens would have a focal length of 6.6 inches and the nearest standard lens 186 lnches.

$$
208 \times R^{2}=688 \text { reet }
$$

The required horlzontel fleld of view of the third most powernul lens is 688 leet. The deslred lens would heve a locel length of 3.6 lnches and the nearest standard lens 184 Inches.

The tentative lens complement is thus four lenses of $22,6,4$, and 2-1nch focal lengthe.

\subsection{Lene Complement}

A 2-4-6-12 inch lens cowplement wlll have mapelfication rat10s of $2,1.5$, and 2 wich are unequal and undesirable from a buman englneering viewoint.

It 10 desirable to be able to scribe a vex pencll line on the monttor tube and 1notruct the operator to chaige to a more powernul lens only when the object belng rleved 18 it thin the 1ndicated area. The lens complement must therefore have unfform magniflcation rat10s. Sultable lenses are $1.5,3,6$, and 22-1nches, all avaliable as stendard, and beving a mopiflcation ratio of 2 hetween conser cutive lenses.

The efield of the 2.5-1nch lens mas be occluded to came extent by the barrel of the 12-Inch lens. The quadrant contalning the occlusion car be specifled. The clear Ileld will still be at least as great as that of a 2-1nch lens. 


\subsection{Lens Flelds of V1ev and Ifmits of Resolving Power}

The approximate horizontel and rertical ilelds of Flew of the recommended lenses are shown in the table below. Also shown is the maxdmum distance at intah a 2-loot high boat can be resolved, based upon the assumution that Ilve scanning Ines are required to resolve the object.

\begin{tabular}{|c|c|c|c|c|}
\hline Iens & Focld 1n & $\frac{\text { et at distance }}{1000 \mathrm{It} .}$ & $\frac{\text { shown }}{200 \mathrm{ft} .}$ & $\begin{array}{l}\text { Max. distance to } \\
\text { resolve boat }\end{array}$ \\
\hline $1.5^{n}$ & $2666 \times 2250$ & $334 \times 250$ & $66 \times 50$ & 550 \\
\hline $3^{n}$ & $833 \times 625$ & $167 \times 125$ & $33 \times 25$ & 2100 \\
\hline $6^{n}$ & $417 \times 313$ & $83 \times 63$ & $16 \times 12$ & 2200 \\
\hline $12^{n}$ & $208 \times 156$ & $41 \times 31$ & $8 \times 6$ & 4400 \\
\hline
\end{tabular}

This table Indicates that it is impractical to survey the river by telerision and detect a small bost a mile upstream and downstream. The 1.5-1nch or poss1bIJ the 3-Inch lenses are the most powernul ones that can be used for general survelllance by autcmatic panning alone and still give a reasonable fleld of Fier at closer ranges. These two leases cannot resolve a small boat bejond 600 to 2100 feet.

It 1s technicaldr. possible to incorporate a programmer which would program an elaborate search pattern involving both pan and t1lt motions with lens changes and speed changes as required. Bowever, the time required for a complete search cycle would leave some areas of the river unobserved for lons perlods of time. We have not worked out such a program, but suspect that a complete search cycle could require a helf bour or longer. A further complication is the necessity of putting the camera equipment and the programer back in step after the operator has stopped the automatic search and manlpulated the equipment manualis.

\subsection{ASPBCT RATIO}

The results of (4.3) and (4.4) suggest that some improvement in resolving pover for long low objects could be obtalned if the normal aspect ratio of 4 wide to $3 \mathrm{hlgh}$ were changed to 3 wlde and $4 \mathrm{hlgh}$. In other vords, the camera could be latd on 1ts side and a apecial monitor used in wich the picture tube and deflection yokes were turned 90 degrees. Thls would give an image 4 units high and 3 units wide.

During a visit to the camera site one can roughly mask out vith his hands the Flelds of v1ew eacompassed by the tro aspect rat1os and observe that the standard 4 to 3 ratio seems best sulted to the terrain.

In a 3 to 4 aspect ratio system the raster (scanning lines on the moultor) would run rertically. This arrangement could be 1rritating to an operator ascustomed to rleving bls home recelver in the normal pattern. 
From (4.4) 1t can be seen that changing the aspect rat10 will allow a small boat to be resolved about 33\% farther aras. Tevertheless, outomatic scanning vith a 1.5-1nch or 3-1nch lens would resolve a boat no farther avas than 800 to 1400 feet respectively. The great majority of the one-mile range of river upstream and downstrean st117 will not be under effective survelliance." lormal aspect ratio should be retalned.

\subsection{N ITHS VERSUS IEITS TURRET}

A $200 \mathrm{~m}$ lens 18 available with a focel length range from 2.4 to 12 inches and an aperture of $1: 5.4$. This range approxdmates that of the 3,6 , and 12 -1nch lenses of a turret. The additional doubling of the linear field of rier made possible with a 1.5-1nch lens in a turret is a distinct adventage when rlewing nearby scenes, and practically a requirement for automatic panning.

With a $200 \mathrm{~m}$ lens the Image will alwass be in the fleld of Flew durfiug a change of poiver. If the operator sees that increasing the pown is causing the Image to meve off the screen; be can correct with the pan and tilt movements. On the other hand, If a turret is used the requirement that the image must be within the prescribed area before the next higher powered lens is selected 18 a positive instruction to which an operstor should essily adjust.

If a turret is used the image will be lost for 2 or 3 seconds during lens change. Th1s disadvantage may not be ser10us. To cross the bor1zontal fleld of view of a 12 Inch lens at 5000 feet in 3 seconds an object would have to be moving about 50 miles per hour.

The maximum aperture of the zoom lens 18 1:5.4. A 1.5-1nch and 3-1nch lens, which would be the only ones effective at night for general survellilance, can be obtalned with aperture of $1: 1.5$, which will pass 13 times more 11ght than $\mathrm{f}: 5.4$. Even $\mathrm{j}$-1nch lens 18 avaliable in $1: 1.8$. These apertures are or lenses listed in reference data in the iriter's I1les, and somewhat faster lenses may be arallable as standard 1tems.

A turret has the further advantage that lenses can be replaced if some other focal length seems more desirable, or a faster lens becomes avallable. For example, there 18 a $15-1$ nch $1: 4.5$ lens and a 20-1nch $f: 4.5$ lens avallable. Also, extremely wide angle lenses ( 10 millimeter focel length) are arallable.

For the proposed application the turret appears to be the better cholce.

\subsection{MOUNTITIO OR PAN AND TIIT UNITI}

If the pan and t1lt unit 18 mounted on a hor1zontal ourface about 50 feet above the vater, is tilted downiard 8 degrees, and the 1.5-inch lens is in use, the 5000 loot horlizon will be near the top of the monitor scene. When the cemera Is the panned to vlew directly across the river, the ecene in view will extend from a near polnt of 180 feet to a far point of at least 5000 feet, unless the upward slope of the land foreshortens this range. 
If a polnt nearer than 280 feet must be vieired during automatic panofing, whlle keeping the 5000 loot range in riew up and durn river, the surface on which the pan and tilt unit 1s mounted will have to be inclined the required amoint tovard the river. IIIs mounting will cause the entire scene on the monftor to be cocked to the left when vlewing upriver, and to the rlght when vlewing downstreem. The apperent rocking motion of the scene during panning could be very annoying to the operator.

\subsection{DOOBSTR}

The environment is such that the samera can be turned directly into the sum during early morning and late evening. The camera must. be equipped with a douser to prevent destroylng the vidicon tube under these conditions. The douser should 1nsert a sharp cutoff infrared 117ter in the optical circult Lefore the sun comes into the fleld of view of the widest angle lens.

The operation of this douser shoula be automatic and there should not be any provision for manual orerride, else the vidicon may be destroyed by operator error.

\subsection{InTUmatros}

\subsection{Range of Searchlights}

Factors wich affect the range of searchlights are object brightness, colos and brightness contrast of object with bicksround, size of object, time of exposure, atmospheric conditions, and vioual acuity of observer (or sens1tivity of IV camera). The table below, from Crouse-Hinds, shows the approximate range in feet of searchlights fos detecting with the eye a medivm sized object such as a car or group of people.

$$
\begin{aligned}
& \text { Beam Gandlepower } \\
& \text { or } \\
& \rightarrow \text { Searchl1ght } \\
& 250,000 \\
& 500,000 \\
& 1,000,000 \\
& 2,000,000 \\
& 3,000,000 \\
& 5,000,000 \\
& 7, \infty 00, \infty 00 \\
& 10,000,000 \\
& 15,000,000 \\
& 25,000,000 \\
& 50,000,000
\end{aligned}
$$

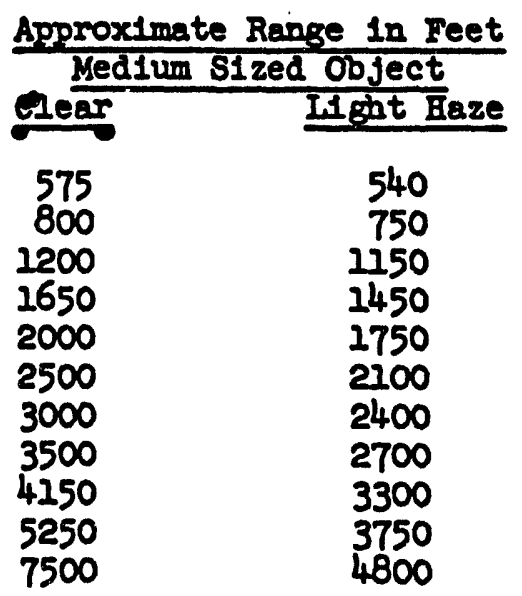

ands table 1s based on detection of the object in view. For recognition, from 2 to 10 times more 11ght, contrast, s1ze, or time will be required. 
Position of the observer with respect to the searchlight is of prime importance. If the observer moves laterally away from the 11ght, the userul range increases. Best conditions usuald exist with the observer from 100 to 300 feet awas from the searchlight.

Under moderate fog conditions a searchlight is of almost no value because of the scattering effect of vater particles and the resultant halo.

\subsection{Belection of Lenre}

Laups with the highest candlepower have the narrowest beam spread, shortest 11fe, and are usually rated for 6,12 , or 32 volts. Projection type lamps are avallable rated at 120 volts but they also have a llfe of only about 50 hours. None of the 1ncandescent lemps sultable for searchlight service are rated for longer than 800 hours. Where continuous duty 18 required, the lamps Ith longest ilfe should be selected.

The approximate angles of vier of the recommended lenses are shown in the table Delor.

\section{Itopel Length of Lens}

$$
2.5 \text { 1nch }
$$$$
\text { - inol }
$$

6 1nch

22 sact

\section{Angle of Viey}

20 degrees

10 degrees

5 degrees

degrees

8 reasonably wide searchlight beam is particularly advantageous in spotting moving objects. The widest beams avaliable in swaller searchlights are about I1ve degrees and are obtalned by uoing medium prefocus floodilght lamps. of course, if several searchllghts are used a wider beam can be obtatined by careful alming of the searchlights, but the beam candlepower will not be increased by this expedient.

Bhort 11fe lamps are not desirable in searchlights operating continuously or wien labor of replacement must be considered in the cost of operation.

These considerstions dictate the selection of medium prefocus floodilght lemps. type $G$, rated 120 volts and 800 hours, of the lamps to be used are of the Incandescent type.

\subsection{Incandescent Versus Mercury Lamps}

Searchlights can be arranged for use of mercury lamps and will produce about ten t1mes the beam candlepower obtalnable with 1ncandescent lamps. These lemps require speciel bellasting and starting equipment. They have the further disadrantages of requiring a varmup time before reaching rull brilliance, and 
a cooling time becore restriking in case ther are turned off or power 1s Interrupted. The cool and restrike time to full brilliance may run as long as 15 to 20 mimutes.

Qther gas discharge lamps gorld probably Increase the beam candieporrer by Cactol of 10 or more also, provlded searchlights can be arranged for such 11ght sources.

Furthes information has been Cequested from Crouse-Hinds on mercury search11ghts. In spite of the1r disadrantages they may be required if night rlewing by telerision is to be seasonnbly practical.

\section{4 searchlights}

Crouse-Binds seaxblizht net felghts and beam candlepowens when oquipped fith type O lncandescent floodlaups are shoy in tia table belo.

\begin{tabular}{|c|c|c|c|c|c|}
\hline Seerchlight & Inst Price & Eight & Beam Candlepoiver & Gandlejovex Per & Pound \\
\hline DES-8 & 425 & $142 \mathrm{bs}$ & 97,000 & - 6,900 & $\because$ \\
\hline DCE-12 & $\$ 250$ & & 560,000 & . & \\
\hline DCE-18 & 450 & & $1,165,000$ & & \\
\hline$x-24$ & 8800 & & $2,310,000$ & & \\
\hline
\end{tabular}

Just to detect an automohile-sized object on clear alght as one mile, with the ere, requires 25 million beam candleporrer. Aclustes of units all precisely aimed at the same solnt would be required to obtain th1s candleporier. Any comblnation of searchlights listed in the table above would be too heary for mounting on a pan and t1re unit. Further, the eye 1s much more sensitive than a vidicon telerision camera. Thus it seems impracticable to provide adequate beam candlepower mounted on a pan and tilt unit to permit a vidicon camera to resolve a small boat a male aray.

It would be possible to mount any required number of searchligits off the pan and t1lt unit, preferably 100 to 300 feet avas laterally. They would. be fixed In direction and because of the1r narrow beam many units would be required to $117 u m$ inate up and down the river. The cost of such an installation would be more than 10 thousand dollars for each 25 million candlepower 5 degree beam, 2. Incendescent searchllghte of 800 hour larm life vere used. Wereury vapor searcblights would probably. reduce this cost considerably. Ang Iloodilght Instellation would be useless under moderate fog conditions.

Carbon are searchlights of the antlilrcraft type profuce about 800 million beam candlepover but require operating personnel. 
It would be practicablo to provlde a cluster of 8 DCs-8 searchlights on a hear duty pan and t1lt unit. The searchlights alone would relgh 112 pounds, cost $\$ 1000$, consume 2000 vatts, and provilde a combined 5 degree beem of only 776,000 candleporrer. Two DCS-12 unfts would produce 720,000 beam candlepover, cost $\$ 500$, consume 1000 watts, and relgh almost 200 pounds. Elther such reight would require a very heary cuty pan and tilt unit.

In elther case a 700,000 candlepover beam is not of much value. Its beam would 11luminate an object the s1ze of a car for detection by eye at 1000 feet on a clear night, but a vidicon camera vould be effective to a shorter distance because it 18 not as sensitive as the eye. Thus more than $80 \%$ of the dastime range of the system would be unobservable at nlght, even in clear weather.

It does not seem just1fleble to spend the runds required -or attaching searchlights to a pan and tilt unit when $80 \%$ or more of the river would still be unobservable. Furtherwore, the movement of the lights as they vere panned would reveal to an interested person the direction of view of the camera.

10.0 CONIROL

10.1 Innct1ons Required

The following control functions are required:

1. Power on-off

2. Pan left

3. Pan right

4. Tilt up

5. Tilt down

6. Ir1s open

7. Ir1s ciose

8. Focus near

9. Tocus far

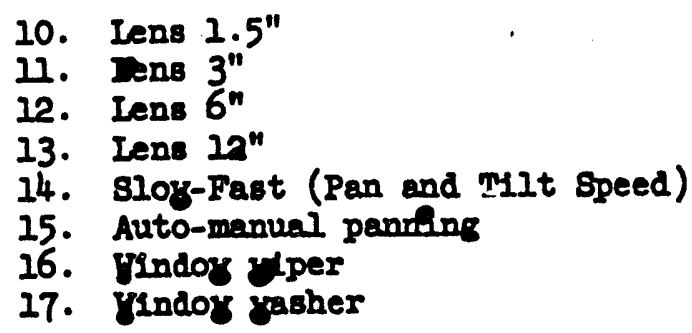

10.2 Control Cable

The control functions require a cable with at lesst 18 ydres. Severul additionel. wires should be Included for contingencles and future use, and for power to the distribution milifer. A sultable cable is G.5. WCD-737, 24 conductors, 110.16 AWG. The 11st price of this cable is $\$ 425$ per thousand feet, or $\$ 2125$ for 5000 seet.

\subsection{Auxillary Relay Renel}

Because of the distance between the control station and the controlled equipment the cable above will not be sultable for direct control of the equipment. The clreult reslstance of I10. 16 wire would be about 50 ohms. Even No. 12 wire has a resistance of about 20 ohms over this alstance, and cable with Io. 12 conductors would cost over $\$ 5000$. 
The problem can be solved by use of an auxlliary relar control penel at the guard torer. Bmall, Inexpensive relays will serve the purpose, and they ena be of the plug-in type for ease of maintenance.

In the Inal desion of the oyotem it may be possible to choose relays and operating roltage auch that lio. 19 ANC control cable can be used inth consequent savings of several hundred dollars in cable cost.

\subsection{Wreless Versus Cabled Circults}

Complete wreless control and pleture transmisaion is not economically feasible. Two trangmitters and two recelvers would be required and the cost would exceed $\$ 30,000$ for equipment alone.

The use of tone signel control over a spare telephone pair 18 possible, but we have no cost data at this time. A messenger cable must atill be installed on the poles to carry the video cable. The opecification should request a b1d based on multiple conductor wired control, but should invite alternate proposals based on multiplexed control if they result in a lower installed cost. It should be noted that multiplexed control would add to the complexity of the system and thus increase malntenance costs, so it should not be cons1dered unless the initial cost saving is substantial.

\subsection{PAI AND TIIT STHWDS}

\subsection{Slor Speed Panning}

8lor panning opeed will be required when the longer focel length lenses are in use. The angle of viev of the 12 -Inch lens $18 \mathrm{2}$ degrees. If ve assume that during panning an object should remain in the Ileld of view for at least 5 seconds, then the maximm panning speed becomes

$$
\frac{2 \text { degrees }}{5 \text { seconds }}=0.4 \text { degree per second, or } 15 \text { minutes per revolution. }
$$

\subsection{Elgh Speed Panning}

Figh speed panning will be required for automatle panning and when the shorter Iocel length lenses are in use. The angle of vlew of the 1.5-Inch lens 18 20 degrees.

$$
\frac{20 \text { degrees }}{5 \text { seconds }}=4 \text { degrees per second, or } 1.5 \text { minutes per revolution }
$$

Thus the high and Ior speed ratio becomes 10 to 1 .

\subsection{THzing Speed}

The rertical angle of vier of the telerision system 1211 be $3 / 4$ of the hor 1 zontal engle because of the $4: 3$ aspect rat1o. For the 12-1nch lens, then, the vertical Ileld is only 1.5 degrees. Agein assuming 5 seconds per fleld of Nev, the required t1lt speed becomes 


\section{$\frac{1.5 \text { degrees }}{5 \text { seconds }}=0.3$ degrees per second, or 20 minutes per revolution}

At this opeed 2.5 minutes rould be required to t1lt the camere through an angle of 45 degrees, and thls 18 too elow to be practical for vierding a nearby fast morling object. Two-speed t1lting as well as paning wlll therefore be required, and with a ratio of 10 to $I$ the high speed tilt would be 3 degrees per second.

\subsection{Summary of V1ewing Times}

With the recomended panning and tilting speeds the seconds of Fleving time w1ll be the same in both the vertical and horlzontal direction. These vieving times for the lour lenses at each speed are summarized in the table below. "Beconds per 11eld" refers to the time required for the Image of a stationary object to cross the monitor screen during panning or tilting. An asterisk indicates that the viewing time 18 probably too fast or too slow for practical use.

Iens

1.5 Inch
3 Inch
6 Inch
12 Inch

Seconds Per Mela

Fast Speed Blor Speed

$\begin{array}{lc}5 & 50 * \\ 2.5 & 25 * \\ 1.2 * & 12 \\ 0.5 * & 5\end{array}$

\subsection{Aspect Rat10}

If a 3 to 4 aspect ratio 18 chosen the recommended pan and t1lt speeds must be interchanged.

\subsection{COST ESPINATIS}

\subsection{Sumary}

Vendor's prime material and purchased parts

$\$ 11,300$

Vendor's labor to assemble and test system before shipment

Verdor's sub-contracted labor and material for installation and test of system

Vendor's design and fleld engineering and contract administration

Vendor's alrect cost

Vendor's overhead at $20 \%$

Vendor's prostt at $10 \%$

Packeng and shlpping 


\subsection{Frime Naterlul and Purchased Parts}

The prime materiel and purchasę parts estimate 18 1temlzed belor to 117ustrate the type of equipwent on which. this estimate is based.

\section{Item}

Eutimated Vendor's Direct Cost

a. Vidicon transistor's red camera

$\$ 2,900$

b. Lens turret, selective (not sequent1al) type, for four lenses

c. Iens $1.5^{n} \quad 1: 1.5$ 100

d. Lens $3^{n} 1: 1.5$ 150

e. Iens $6^{n} 1: 2.8$ 270

1. Iens $22^{\prime \prime} 1: 4.5$ 500

8. Speciel support for $12^{n}$ lens 70*

h. Douser with infrared fllter 230*

1. Weatherproof housing for camere and lens; Includes heater, blower, washer and wiper

j. Pan and tilt unit, very beavy duty, to carry at least 200 pounds, v1th speclal tro-speed pan and t1It speeds, weatherproor, automatic panning

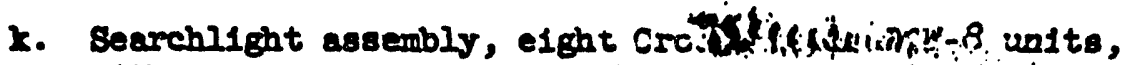
with mounting platform and hardware

1. Remote control anofliary rèlay and contactor panel with cabinet

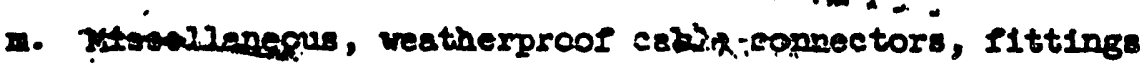
and cable nets

$$
\text { - oneseni. }
$$

220

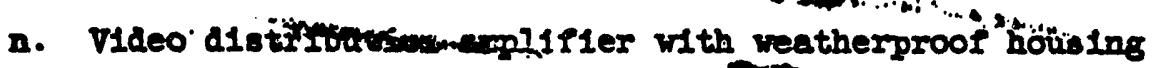

o. Wonftor, 14 1nch, rack mounted

p. Control station at =enstion for gontrol of all functions

q. Wonttor rack assembly, power supplies, civises, connectors, etc.

* Ilat price or other cost data not avallable. Bst1mate shown 1s tentative. 

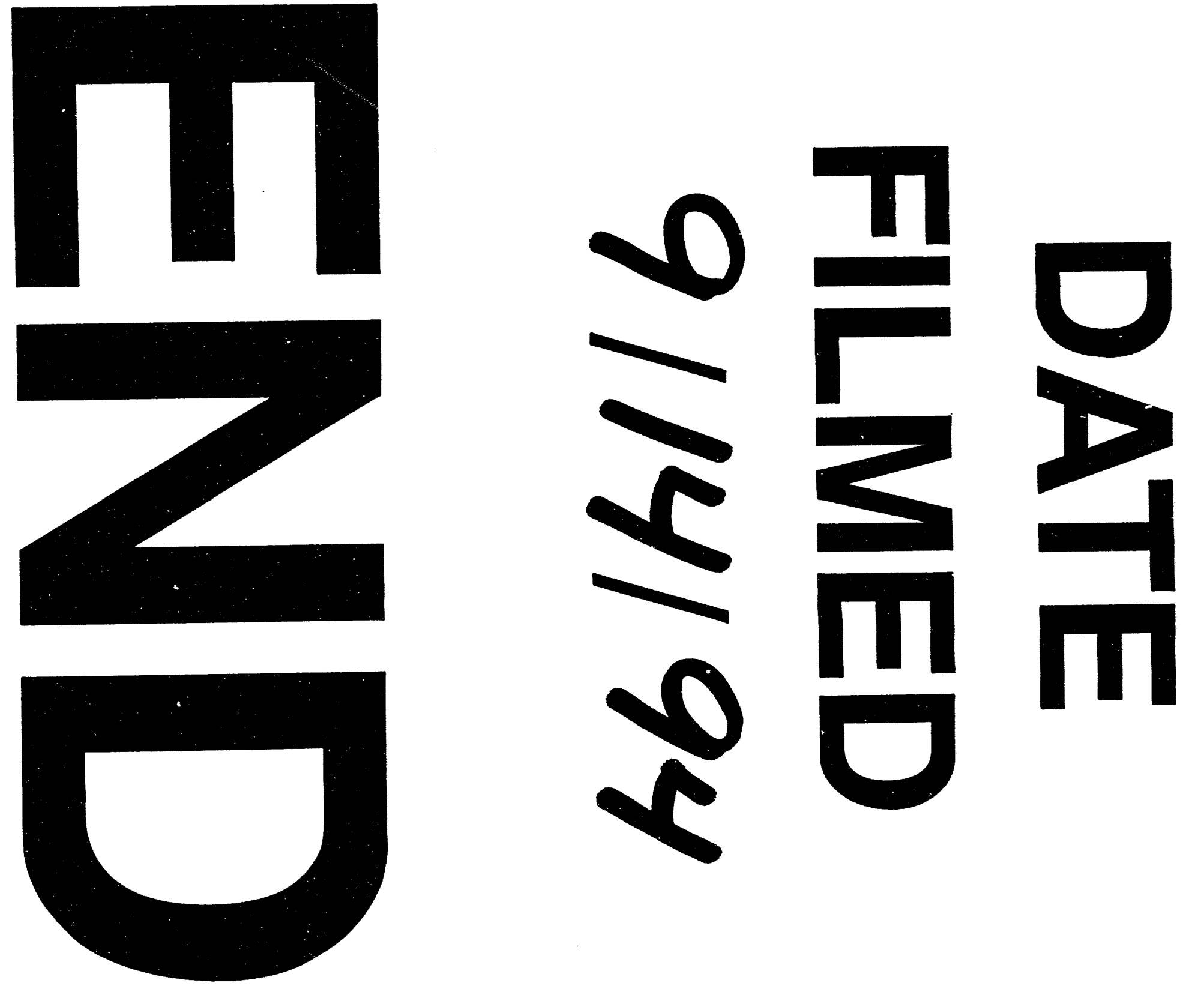
